\title{
39.スーパーパラホラ曲線とパラポラ曲線を用いた高度㲹光制御蛍光 灯用反射笠による管面の䄈度上昇と配光の比较
}

\author{
吉田幹朗 椎名岳人 山田真士 池田紘一 \\ （東京理科大学）
}

\section{1.はしめに}

本研究の目的は、オフィスや学校などの照明環境にお いてグレアや光幕反射の少ない質の高い快適空間を構筑 するための優れた照明器具の設計、つまりこのような不 快と感じる反射を抑えた配光制御をし、また輝度上昇も 抑え、さらに高効率の蛍光灯反射笠を設計することであ る。

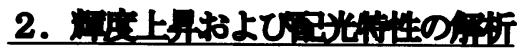

再帰光輝度上昇解析プログラムと 3 次元配光予測プロ グラムを用いて反射笠面での主な反射光である拡散反射 光と正反射光の割合を変化させ、そのときの蛍光管の輝 度上昇・配光・効率の変化を解析した。笠は特殊な曲線 であるパラボラ曲線やスーパーパラボラ曲線を用いた 6 種類の笠を設計し、それぞれの反射面での拡散反射率と 正反射率の合計を $90 \%$ とし、拡散反射率を $0 \% 、 15 \% 、 30 \%$ 、 45\%、60\%、75\%、90\%と 15\%刻みで変化させ、そのときの輝 度上昇を再帰光解析プログラムで解析し、また 3 次元配 光予測プログラムて配光を解析してさらにそれらを可視 化した。そして、パラボラ曲線とスーパーパラボラ曲線

（図 1）のこれらの結果を比較し、どちらがより優れて いるか検討した。
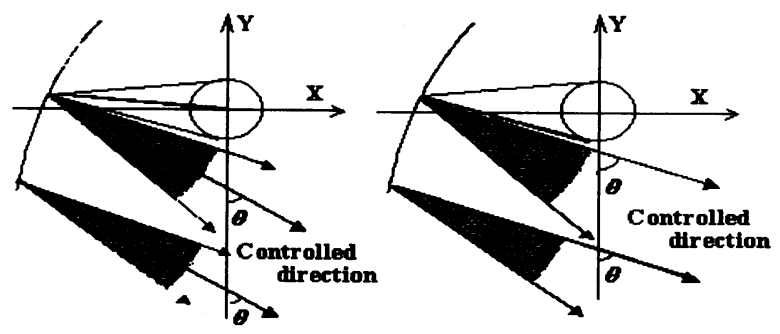

図 1. 特殊曲線（左 : パラボラ曲線、右; スーパーパラ ボラ曲線)
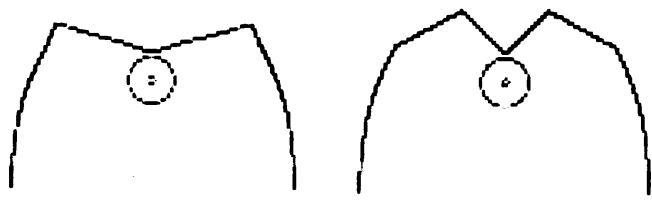

図 2. BATWING TYPE(左) と SWALLOW TYPE(右) の笠

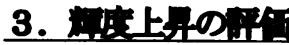

どの笠も拡散反射率が増加するに従って輝度は上昇し たが、それは笠上部で反射された光線が管に戻ってくる 再帰光によるためである。今回設計した笠の中では、特 に鉛直下方向に強い配光をもつSWALLOW TYPE、EAGLE TYPE、 ANGEL FISH TYPE が輝度上昇を抑えていた。

\section{R*osii-}

配光図では、拡散反射率が $60 \%$ 以上になると配光制 御が難しくなった。逆にいえば、0\%〜45\%までは配 光制御がなされていて、 $0 \%$ の場合は部分的に明るくな り寸ぎるため、反射笠は $15 \%$ ～ $45 \%$ 藏していると いえる。また、配光制御の点でもスーパーパラボラ曲線 の方が優れていた。これは、パラボラ曲線がグレア光と なる鉛直角 $60^{\circ}$ 以上の光線をカットするために制御角 を $35^{\circ}$ にしなければならず、そのため反射グレア光の 原因である $15^{\circ} \sim 35^{\circ}$ の光線を強く出してしまうた めであり、逆にスーパーパラボラ曲線は制御角を $60^{\circ}$ と設定すれば鉛直角 $60^{\circ}$ 以上のグレア光を完全に遮光 し、なおかつ $15^{\circ} \sim 35^{\circ}$ の反射グレア光も抑えるこ とができるからである。上から見た配光分布図では、ス 一パーパラボラ曲線のほうが理想的に、かつ、強く光が 出ていることがわかった。

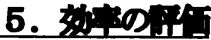

効率は、どの笠も 70\%をこえる高効率になった。このこ とにより、測定で使用した 6 種類の笠の形の良さがわか る。また、パラボラとスーパーパラボラの比較はあまり 相違なく、どちらも高い効率の照明器具を設計するのに 適していることがわかる。これにより、省電力設計が可 能となる。

\section{6. まとめ}

輝度上昇、配光、効率の評価からオフィスなどの照明 環境において質の高い快適空間を構築する蛍光灯用反射 笠は、スーパーパラボラ曲線を用いた抬散反射率 $30 \%$ か ら 45\%の笠が適しているといえる。

Comparison of Luminance Increment on Tube Surface and Light Intensity Distribution of Luminaire of High Efficiency Reflector with Highly Controlled Light Intensity Distribution using The Superparabora Curve and The Parabora Curve. : Mikio YOSHIDA, Takehito SHIINA, Masashi YAMADA and Koichi IKEDA (TOKYO RIKA DAIGAKU) 


\section{BATWING TYPE}

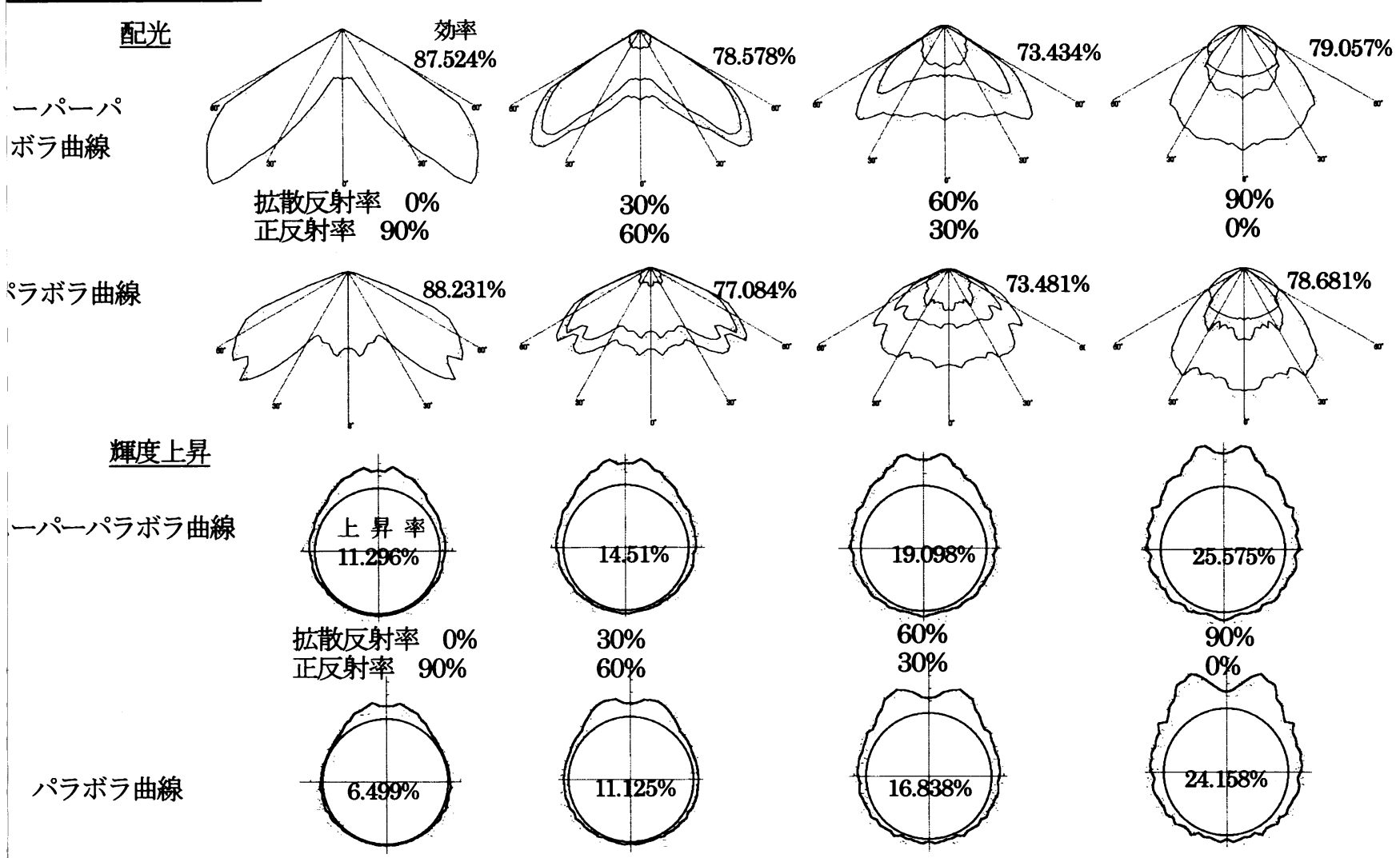

\section{SWALOOW TYPE}

配光

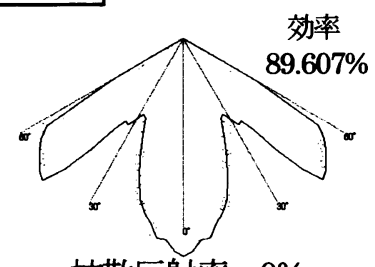

拡散反射率 $0 \%$

正反射率 $90 \%$

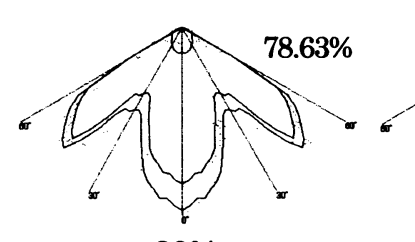

$30 \%$

$60 \%$

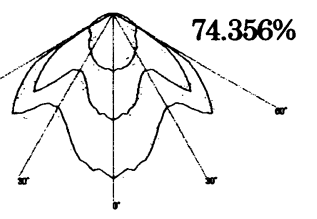

$60 \%$

$30 \%$

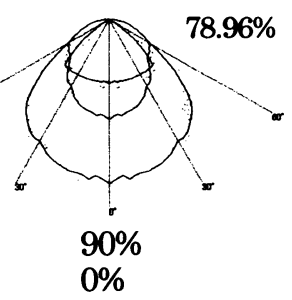

ペラボラ曲線

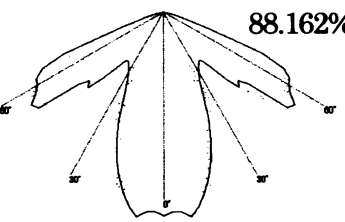

輝度上昇

・ーパーパラボラ曲線

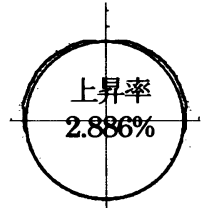

拡散反射率 $0 \%$

正反射率 $90 \%$

パラボラ曲線

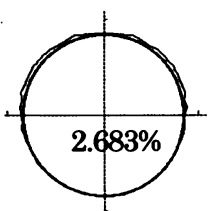

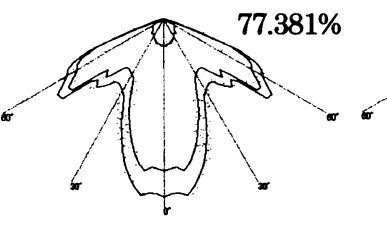

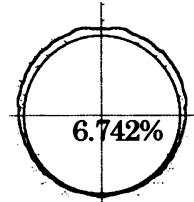

$30 \%$

$60 \%$
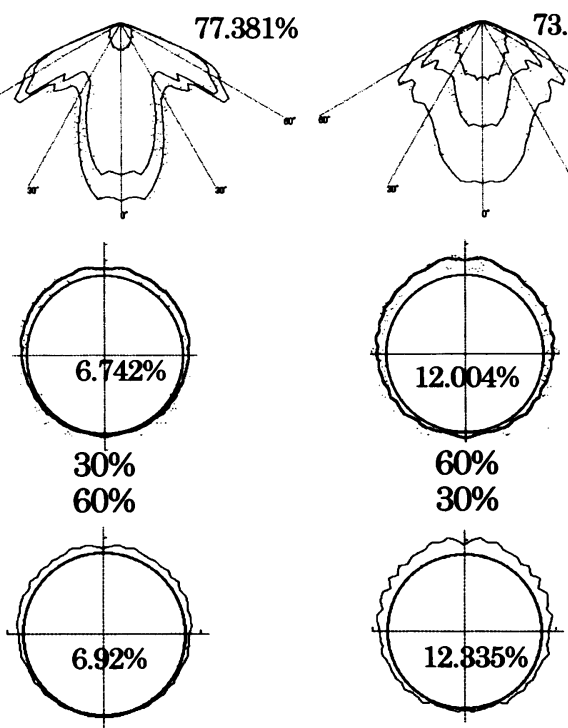

$60 \%$
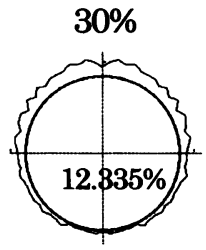

$3.727 \%$

$79.31 \%$

図 3.代表的な笠における配光と輝度上昇の変化と特殊曲線による比較 